Gut, 1975, 16, 205-208

\title{
A study of the cellular infiltrate of the proximal jejunal mucosa in ulcerative colitis and Crohn's disease
}

\author{
R. FERGUSON, R. N. ALLAN, AND W. T. COOKE \\ From the Nutritional and Intestinal Unit, The General Hospital, Birmingham
}

SUMMARY The cellular infiltrate of the proximal jejunum has been compared between 20 subjects without gastrointestinal disease, 20 subjects with ulcerative colitis, and 26 subjects with Crohn's disease. A significant increase $(P<0.001)$ in the plasma cell infiltrate was noted in subjects with ulcerative colitis and a more marked increase in subjects with Crohn's disease $(P<0.0001)$. Such increases may be relevant to raised serum IgA levels following panproctocolectomy for ulcerative colitis or recurrence in the small intestine in Crohn's disease.

Villous abnormalities and histochemical changes have been described (Salem and Truelove, 1965: Jankey and Price, 1969: Binder, Söltoft, and Gudmand-Höyer, 1974) in the jejunum in patients with ulcerative colitis, a disease traditionally considered to affect the colon alone. Crohn's disease, on the other hand, may affect any part of the gastrointestinal tract and typical granulomata have been reported on peroral biopsy of the proximal small bowel (Hermos, Cooper, Kramer, and Trier, 1970). Animal experiments indicate that immunological mechanisms are involved in the maturation of the normal cell population in the proximal jejunum (Crabbé, Bazin, Eysen, and Heremans, 1968: Kenworthy, 1970). Immunological mechanisms are also thought to be concerned in the pathogenesis of inflammatory bowel disease (Kraft and Kirsner, 1971). Therefore, the inflammatory cell infiltrate of the proximal jejunum in patients with inflammatory bowel disease may be relevant. In this paper we report our findings in this respect in patients with ulcerative colitis and Crohn's disease, and consider the possible influence of disease activity, the extent of disease, and steroid therapy on such changes.

\section{Methods}

CLINICAL

The individuals in this series are considered to have ulcerative colitis or Crohn's disease according to acceptable criteria (Lockhart-Mummery and Morson, 1960; Lockhart-Mummery and Morson, 1964; Received for publication 16 January 1974.
Linder, Marshak, Wolf, and Janowitz, 1963). Eleven patients with ulcerative colitis and 19 patients with Crohn's disease were randomly selected from those attending the Nutritional and Intestinal Unit for inclusion in this study solely on the basis of their informed consent for jejunal biopsy. In addition, nine patients with ulcerative colitis and seven patients with Crohn's disease were included as they had already had a jejunal biopsy performed as part of their preliminary investigations before the diagnosis of ulcerative colitis or Crohn's disease had been established. Thus, 20 patients had histological and radiological evidence of ulcerative colitis, and of these seven had active disease, six were on steroid therapy, eight had total colonic involvement, five had distal colonic involvement, and seven had previously undergone panproctocolectomy. Sixteen of the 26 patients with Crohn's disease had active disease and six were on steroids. Four patients were known to have jejunal involvement, of whom three had colonic involvement in addition. Six patients had terminal ileal and colonic involvement, three had colonic involvement only, and four had ileal involvement alone. Eight patients with disease of the terminal ileum and colon and one patient with colonic disease had undergone resection of all macroscopically involved bowel, within five years preceding the study, and had no evidence of recurrence.

As controls, 20 randomly selected, grossly obese patients, who were undergoing jejuno-ileal bypass, were studied. None of these patients had gastrointestinal symptoms. 
The levels of haemoglobin, serum albumin, and seromucoids are routinely determined in the Nutritional and Intestinal Unit. A patient was classified as having active disease at the time of jejunal biopsy if the serum albumin was less than $4 \mathrm{~g}$, serum seromucoids greater than $150 \mathrm{mg}$, and haemoglobin less than $12.5 \mathrm{~g}$ per $100 \mathrm{ml}$. The duration of illness was assessed as from the time of the initial symptoms.

\section{HISTOLOGY}

Jejunal biopsies were obtained from the subjects with inflammatory bowel disease using a suction multiple biopsy capsule (Roy-Choudhury, Nicholson, and Cooke, 1964) under fluoroscopic control, and at operation from the control group of patients. All specimens were taken from the first $10 \mathrm{~cm}$ of jejunum, and after preliminary orientation under a dissecting microscope, sections $5 \mu$ thick were prepared, stained with haemotoxylin and eosin, and examined microscopically. Cell counts were performed in at least three areas of each section (Ferguson, Asquith, and Cooke, 1974). Using a binocular light microscope with a graticule placed in the eyepiece dividing the visual field into equal squares, cells in each of 50 squares of lamina propria and 50 squares of epithelium were counted, and the numbers so obtained were multiplied by the appropriate correction factor to give the number of cells per square $\mathrm{mm}$ of lamina propria and per $\mathrm{mm}$ length of epithelium. If lymphoid follicles or focal collections of lymphocytes were seen in the sections studied, then only areas away from such lesions were selected for counting. In the lamina propria, the plasma cells, lymphocytes, eosinophils, neutrophils, reticulum cells and other cells (fibroblasts, histiocytes, and unclassified cells) were counted, the sum of these being the total cell count. In the epithelium the number of lymphocytes per $\mathrm{mm}$ length was counted. Statistical analysis was performed on the results using Student's $t$ test.

\section{Results}

\section{CELL COUNTS}

The results of the cell counts in the three groups of patients studied are shown in the table. There were no statistical differences between the groups with respect to the number of eosinophils, reticulum cells or 'other cells' in the lamina propria, and these results are not further considered.

\section{LYMPHOCYTE COUNTS}

There were no significant differences in the lymphocyte counts of either the lamina propria or the epithelium between the three groups studied. Neither in ulcerative colitis nor in Crohn's disease were the lymphocyte counts in the lamina propria different in those patients with active or inactive disease $(P=0 \cdot 2)$. Nor did the patients receiving steroid therapy or with a greater duration of disease have differing counts from the others $(P=0 \cdot 3)$. The counts in patients who had had previous excisional surgery of all macroscopically diseased bowel were not distinguishable from those whose abnormal bowel remained $(P=0 \cdot 3)$, whilst in patients with ulcerative colitis, the counts in those with left-sided colonic involvement alone are similar to those with total colonic involvement $(P=0 \cdot 2)$. In patients with Crohn's disease, the counts of those patients with jejunal disease, ileal disease, and colonic disease were also similar. The intraepithelial lymphocyte counts in patients with inflammatory bowel disease of both types were identical to the normal controls.

\section{PLASMA CELL COUNTS}

Significant differences were noted in the lamina propria plasma cell population between the three groups. Patients with ulcerative colitis had raised counts $(P<0.001)$ compared with controls, and subjects with Crohn's disease had raised counts compared with the ulcerative colitis group $(\mathrm{P}<0.05)$

\begin{tabular}{|c|c|c|c|c|c|c|c|}
\hline & \multicolumn{6}{|c|}{ Lamina Propria/mm² } & \multirow{2}{*}{$\frac{\text { Epithelium/mm }}{\text { Lymphocytes }}$} \\
\hline & Plasma Cells & Lymphocytes & Eosinophils & Reticulum Cells & 'Others' & Total & \\
\hline $\begin{array}{l}\text { Controls (20) } \\
\text { Mean } \\
\text { SE }\end{array}$ & $\begin{array}{r}1050 \\
101\end{array}$ & $\begin{array}{r}2971 \\
178\end{array}$ & $\begin{array}{r}313 \\
42\end{array}$ & $\begin{array}{r}230 \\
32\end{array}$ & $\begin{array}{r}2773 \\
155\end{array}$ & $\begin{array}{r}7413 \\
236\end{array}$ & $\begin{array}{r}53 \\
5\end{array}$ \\
\hline $\begin{array}{l}\text { Ulcerative colitis (20) } \\
\text { Mean } \\
\text { SE }\end{array}$ & $\begin{array}{r}2268 \\
248\end{array}$ & $\begin{array}{r}3044 \\
344\end{array}$ & $\begin{array}{r}242 \\
64\end{array}$ & $\begin{array}{r}240 \\
27\end{array}$ & $\begin{array}{r}2096 \\
173\end{array}$ & $\begin{array}{r}7621 \\
474\end{array}$ & $\begin{array}{r}50 \\
2\end{array}$ \\
\hline $\begin{array}{l}\text { Crohn's disease (26) } \\
\text { Mean } \\
\text { SE }\end{array}$ & $\begin{array}{r}3002 \\
232\end{array}$ & $\begin{array}{r}2566 \\
182\end{array}$ & $\begin{array}{r}215 \\
58\end{array}$ & $\begin{array}{r}366 \\
58\end{array}$ & $\begin{array}{r}1881 \\
86\end{array}$ & $\begin{array}{r}8072 \\
273\end{array}$ & $\begin{array}{r}53 \\
4\end{array}$ \\
\hline
\end{tabular}

Table The cellular population of the proximal jejunum in controls and subjects with inflammatory bowel disease 
and with the normal controls $(P<0.0001)$. In patients with inflammatory bowel disease, no significant differences were noted between patients with active or inactive disease $(P=0 \cdot 2)$ or between those on steroid therapy and those not $(P=0 \cdot 3)$. In addition, in patients with ulcerative colitis no significant differences were noted between patients with total colonic involvement and those with distal colonic involvement $(P=0 \cdot 2)$, nor between all of these patients and those who had undergone previous panproctocolectomy $(P=0 \cdot 2)$. In patients with Crohn's disease the counts of those patients with jejunal disease, ileal disease, colonic disease, and those who had undergone resection were in no way distinguishable.

\section{PLASMA CELL: LYMPHOCYTE RATIO}

In patients with Crohn's disease the number of plasma cells per square mm of lamina propria was greater than the number of lamina propria lymphocytes in 15 biopsies. This ratio of cells was not related to disease activity, extent or duration of disease, or to therapy. By contrast, in subjects with ulcerative colitis only four had a greater number of plasma cells than lymphocytes in the jejunal biopsy. Of these four subjects, three had active disease.

\section{Discussion}

Animal experiments (Crabbé et al, 1968: Kenworthy, 1970) indicate that the presence of plasma cells in the lamina propria is secondary to antigenic stimulation. In coeliac disease, where gluten is presumed to be antigenic, there are greatly increased numbers of plasma cells in the lamina propria of jejunal biopsies taken from patients on a normal diet (Ferguson et al, 1974). It could be surmised therefore that the plasma cell counts in patients with inflammatory bowel disease, although significantly lower than in coeliac patients on a normal $\operatorname{diet}(P<0.001)$, were consequent on an abnormal antigen present in the proximal intestine. Alternatively the plasma cells were present as a response to a substance not normally recognized as antigenic. A further feature of the plasma cell increase in both groups was that plasma cells appeared to be situated peripherally in the villi as well as in their normal situation (Crabbé and Heremans, 1966) around the crypts, a finding similar to that encountered in small bowel infestation (Montgomery and Shearer, 1974). These findings may also have some relevance to the high IgA value noted in inflammatory bowel disease (Kraft, Ford, McLeery, and Kirsner, 1968) for part of the serum IgA is produced by plasma cells situated in the lamina propria of the small intestine (Vaerman and Heremans, 1970).

The lymphocytic concentrations in the lamina propria were not significantly different between the groups, but subjects with Crohn's disease did tend to have lower counts than normal controls, a comparable finding to that in coeliac disease (Ferguson et al, 1974). In addition, patients with Crohn's disease tended to have increased numbers of plasma cells compared with lymphocytes in the lamina propria, a trend also seen in coeliac disease (Ferguson et al, 1974) but not in patients with ulcerative colitis. The significance of this is not clear. The function and origin of the intraepithelial lymphocytes is ill understood (Kraft and Kirsner, 1971) and it may be that the number of $T$ cells and $B$ cells differ in these various conditions. This study does not indicate whether lymphocytes have any importance in inflammatory bowel disease but confirms previous reports (Salem and Truelove, 1965: Jankey and Price, 1969: Binder et al, 1974; Hermos et al, 1970) that abnormalities can occur in the proximal jejunum in patients with ulcerative colitis and patients with Crohn's disease, including those with colonic involvement only. Such changes were not related to disease activity as had been noted by Salem and Truelove (1965) and Jankey and Price (1969).

Finally, in individual patients, a jejunal biopsy in the absence of granuloma formation may not help to differentiate between ulcerative colitis or Crohn's disease for the small bowel can be abnormal in both conditions. The existence of such cellular changes in macroscopically normal bowel may have some significance in considering the problems of recurrence in Crohn's disease and also the raised serum levels of IgA in ulcerative colitis after panproctocolectomy (Kraft et al, 1968).

R.F. is in receipt of a grant from the Endowment Fund of the Birmingham Area Health Authority (Teaching).

\section{References}

Binder, V., Söltoft, J., and Gudmand-Höyer, E. (1974). Histological and histochemical changes in the jejunal mucosa in ulcerative colitis. Scand. J. Gastroent., 9, 293-297.

Crabbé, P. A., Bazin, H., Eyssen, H., and Heremans, J. F. (1968). The normal microbial flora as a major stimulatus for proliferation of plasma cells synthesising $\operatorname{IgA}$ in the gut: the germ free intestinal tract. Int. Arch. Allergy, 34, 362-375.

Crabbé, P. A., and Heremans, J. F. (1966). The distribution of immunoglobulin containing cells along the human gastrointestinal tract. Gastroenterology, 51, 305-316.

Ferguson, R., Asquith, P., and Cooke, W. T. (1974). The dejunal cellular infiltrate in coeliac disease complicated by lymphoma. Gut, 15, 458-461.

Hermos, J. A., Cooper, H. L., Kramer, P., and Trier, J. S. (1970). Histological diagnosis by peroral biopsy of Crohn's disease of the proximal intestine. Gastroenterology, 59, 868-873. 
Jankey, N., and Price, L. A. (1969). Small intestinal histochemical and histological changes in ulcerative colitis. Gut, 10, 267269.

Kenworthy, R. (1970). Effect of Escherichia coli on germ-free and gnotobiotic pigs. I. Light and electron microscopy of the small intestine.J. comp. Path., 80, 53-63.

Kraft, S. C., Ford, H. E., McLeery, J. L., and Kirsner, J. B. (1968), Serum immunoglobulin levels in ulcerative colitis and Crohn's disease. (Abstr.) Gastroenterology, 54, 1251.

Kraft, S. C., and Kirsner, J. B. (1971). Immunological apparatus of the gut and inflammatory bowel disease. Gastroenterology, $60,922-951$.

Linder, A. E., Marshak, R. H., Wolf, B. S., and Janowitz, H. D. (1963). Granulomatous colitis: a clinical study. New Engl. J. Med., 269, 379-385.

Lockhart-Mummery, H. E., and Morson, B. C. (1960). Crohn's disease (regional enteritis) of the large intestine and its distinction from ulcerative colitis. Gut, 1, 87-105.

Lockhart-Mummery, H . E., and Morson, B. C. (1964). Crohn's disease of the large intestine. Gut, 5, 493-509.

Montgomery, R. D., and Shearer, A. C. I. (1974). The cell population of the upper jejunal mucosa in tropical spruce and postinfective malabsorption. Gut, 15, 387-391.

Roy-Choudhury, D. C. R., Nicholson, G. M, and Cooke, W. T. (1964). Simple capsule for multiple intestinal biopsy specimens. Lancet, 2, 185-186.

Salem, S. M., and Truelove, S. C. (1965). Small-intestinal and gastric abnormalities in ulcerative colitis. Brit. Med J., 1, 827-831.

Vaerman, J. P., and Heremans, J. F. (1970). Origins and molecular size of Immunoglobulin A in the mesenteric lymph of the dog. Immunology, 18, 27-38. 